\title{
The Relevance of Material and Environmental Conditions on Average Course Times in the Largest Ski-Mountaineering Race of the Alps - Patrouille Des Glaciers
}

\author{
Benedikt Gasser* \\ Swiss Health \& Performance Lab, Institute of Anatomy, University of Bern, Baltzerstrasse, Switzerland
}

Submission: March 26, 2019; Published: April 09, 2019

*Corresponding author: Benedikt Gasser, Swiss Health \& Performance Lab, Institute of Anatomy, University of Bern, Baltzerstrasse, Switzerland

\begin{abstract}
Background: Backcountry skiing has become more and more popular. The development of skis and equipment has been impressive and suggests that achieving a good performance level is much easier today than it was in the past. Taking the most popular backcountry skiing race in Switzerland, the Patrouille des Glaciers (PdG), we addressed the question as whether Material and environmental conditions determine average course times.
\end{abstract}

Methods: The average course times for the original course Zermatt - Arolla - Verbier were analyzed concerning effects of material and environmental conditions such as weather, wind, temperature from 2004 to 2014. Multiple linear regression taking material and environmental conditions into account were calculated in order to decipher effects of material and environmental conditions on average course times.

Results: High coefficient of determinations especially in top patrols (R2 around 0.25) were detected with the calculated models allowing associating material improvements and good environmental effects as having high relevance on course times

Discussion: Based on the calculations in combination with the assumptions an improvement of material is likely to suggest having relevance for course times. Furthermore, an effect of environmental conditions such as temperature, snow, wind and sun are very likely to have in addition relevance on course times. Probably the improved material can explain quite well, that nowadays also recreational alpinists can secure absolve PdG.

Keywords: PdG; Zermatt-Arolla-Verbier; Equipment; Environmental Conditions

\section{Introduction}

Back country skiing gained increased attraction probably also as a consequence of the improved material allowing also the broad mass to absolve nice ski tours [1,2]. In Switzerland with the current climatic conditions around half a year from November to April backcountry tours can be made [3,4]. In this study the most popular ski-mountaineering race of Switzerland (PdG) is addressed. The race of PdG is till nowadays unchanged and starts in Zermatt to Tête Blanche 3650 Meter, to Col du Bertol and Arolla to Rosablanche and Verbier [5]. In patrols constituting of 3 alpinists a length of $53 \mathrm{~km}, 3994$ meters ascents and 4090 Meter descents are absolved. Organizations had to act for satisfying the increased demand to participate at PdG. From the 2006 race two start fields (Thursday/Friday and Saturday/Sunday) were necessary to at least somehow satisfy the constantly increased demand to participate [5]. Undoubtedly, general conditions such as weather, temperature and wind have an influence on physical capacity to absolve a ski-mountaineering race [6-12]. Besides general weather conditions especially snow conditions are to mention [13]. Snow conditions have a direct influence on the friction of skis and therefore the necessary physical work that must be performed to move forward [13]. Due to friction water films are generated which are responsible for the deep friction of skis on snow, whereby interestingly friction seems to become smaller when gliding several times over the same snow [13-21]. Furthermore, the wind conditions are to mention which when strong enough letting temperatures around zero to be felt as minus twenty degree $[3,4]$. Undoubtedly, temperatures have an influence on several aspects of metabolism such as kidney to cardiovascular system [22-25]. Besides the shire necessity to carry warm clothes limiting movements further adverse effects are to mention. Deep temperatures can yield to bronchoconstriction limiting pulmonary capacity [10]. The lower oxygen partial pressure yields to a lower saturation of oxygen [25]. Furthermore, sun and fog are to mention having an effect on viewing: under sunny conditions it is highly easier to ski down compared to foggy conditions. 
Besides the environmental condition's material is to mention potentially affecting successful participation. The originally several kilo heavy wooden skis were replaced by light wood-carbon skis or wood-polymer combinations [5]. Furthermore, skis were getting shorter and smaller and are with binding only around $2 \mathrm{~kg}$ per pair and therefore one third of what normal backcountry skis used to be 30 years ago [5]. Especially in the binding area an enormous development took place whereby especially Dynafit in combination with its special shoe construction yielded to a reduction of weight down to some 100 grams [5]. Furthermore, a development to light highly functional shoes only around 100 gram heavy allowing despite the lightness to absolve difficult downhills without difficulties allowed to improve security and fastness. The above mentioned illustrate the impressive development in material over the last years yielding to the effect that even recreational alpinists can absolve large challenges such as PdG. This yields to the aim of the study. Is there a relationship between the average course times and the material and environmental conditions at PdG. As Hypothesis with potential falsification it shall be stated that there is no effect on course time of Material and environmental conditions on average course times at the biggest ski-mountaineering event of the West-Alps PdG [26].

\section{Material \& Methods}

\section{Participants}

Participants of PdG from the original race from Zermatt Arolla - Verbier were analyzed. PdG takes place every second year, however in 2012 environmental conditions (especially avalanche danger) races were not started. Furthermore, the second start field in 2006 was canceled. In consequence, average course times for the years of 2004, 2006 (only the first race), 2008, 2010, 2014 were analyzed.

\section{Procedures \& Statistical Analysis}

To analyze average course times participants were separated in top patrols - the first ten places - and median patrols (the median patrols - the ten patrols of the middle of the result list). For the median patrols the following procedure was chosen to identify relevant patrols : median value of start list (when number was uneven the upper place was used - over median) the four places before (over-) Median, the median, and the four places behind the median and in addition the average of the time of the place five places before respectively behind of (over-) median of course time from result list was taken as calculation base. Furthermore, in order to analyze effects of material and conditions (wind, temperature, snow) multiple linear regression models with calculation of coefficient of determination were calculated. Material variable (M) as well as environmental variable (WTS) were modulated in order to receive models of high validity. Material variable was calculated as linear as well as exponential decrease over the years. In principle, linear decreasing trends were modulated in order to approximate the improved material yielding to decreasing physiological requirements when absolving PdG. The decreasing process was modulated as follows: $\mathrm{M}(\mathrm{t})=\mathrm{Mt}-1^{*} \alpha$, whereby $\alpha$ as approximation for the decreasing physiological requirements due to improved material was dependent on model assumption $(\alpha=3,6,9,12,15,18,21$ or 24$)$ percent respectively.

Weather conditions the so called WTS Variable (weather, temperature, snow) was approximated in the following way: either conditions were taxed as good or conditions were taxed as bad. When conditions were taxed bad the value of one was attributed indicating that high physical requirements were necessary for successful absolving. When conditions were taxed as good a lower value indicating that physical requirements are only e.g. 80 percent compared to hard conditions a lower value of 0.8 was attributed to the WST variable in the model. Values of WST were ranging from $0.76<$ WTS $<1$. Considerations if a discount was attributed for the respective year were as follows: In 2004 general conditions were very good and it was a flat high pressure situation since the middle of April [27]. Only little rain in the beginning of the race, during the day very good view, yielding to a new best time of $6: 31,42$. The value of the WTS Variable was therefore discounted and between $0.76<$ WTS $<$ 0.97. In 2006 were in general very good conditions with good snow and weather conditions resulting in a new best time. The April days were warmer than usual, especially the days before the race from 20-26. April [27]. In men a new best time of 6 hours 18 minutes and 48 seconds resulted. The value of the WTS Variable was therefore discounted and between $0.76<$ WTS $<$ 0.97 .

In 2008 some signs existed that as a consequence of strong wind and snowfall the race could not be started. Temperature was lower than usual in April [27]. Low pressure areas were present over the alps and only from 26. to 27. April a high pressure situation was present, and weather was dry [27]. In men no new best time resulted and the fastest patrol was in 6 hours 24 minutes and $32 \mathrm{sec}$ fast. The value of the WTS Variable was therefore one. In 2010 under very good conditions a new best time of $5 \mathrm{~h} 52$ minutes resulted, whereby the excellent conditions were also due to sunny weather during the whole month [27]. The general weather conditions were very good in the second half of April [27] Pinpointing the spring conditions slower patrols were due to increased avalanche danger stopped and evacuated [28]. The value of the WTS Variable was therefore below one between $0.76<$ WTS < 0.97. In 2012 the race was due to miserable weather conditions not started and analysis in consequence were not possible. In 2014 the April was very sunny in whole Switzerland and to warm compared to previous years [27]. Due to not always optimal conditions no new best time resulted. The value of the WTS Variable was therefore below one between $0.76<$ WTS $<0.97$. Based on the above in a second step multiple multivariate regressions were conducted in the following way course timei $=\mathrm{mi}+\mathrm{wsti}+\mathrm{e}$ for the top patrols as well as for the median patrols. Analysis was conducted with Microsoft Excel. 
Results

Table 1a \& 1b: Coefficients, p-values and coefficient of determinations for the different calculated multilinear regression analysis for top patrols.

\begin{tabular}{|c|c|c|c|c|c|c|c|c|c|c|c|c|c|c|c|c|c|c|}
\hline $\begin{array}{c}\text { Decrease percen } \\
\text { Material }(\alpha) / \text { WST }\end{array}$ & 0.97 & 0.8 & 0.94 & 0.8 & 0.91 & 0.8 & 0.88 & 0.8 & 0.85 & 0.8 & 0.82 & 0.8 & 0.79 & 0.8 & 0.76 & 0.8 & 0.73 & 0.8 \\
\hline $\begin{array}{c}\text { coefficent M } \\
\text { (p-value) }\end{array}$ & 13.6 & 0.004 & 7.163 & 0.003 & 5.037 & 0.003 & 3.983 & 0.003 & 3.357 & 0.003 & 2.944 & 0.003 & 2.653 & 0.003 & 2.438 & 0.003 & 2.385 & 0.004 \\
\hline $\begin{array}{c}\text { coefficent WST } \\
\text { (p-value) }\end{array}$ & 6.1 & 0.001 & 6.117 & 0.001 & 6.126 & 0.001 & 6.132 & 0.001 & 6.135 & 0.001 & 6.135 & 0.001 & 6.131 & 0.001 & 6.123 & 0.001 & 6.053 & 0.001 \\
\hline $\begin{array}{c}\text { Coefficent of } \\
\text { determi-nation } \\
\text { R2 }\end{array}$ & 0.2272 & & 0.2284 & & 0.2294 & & 0.2303 & & 0.2309 & & 0.2312 & & 0.2313 & & 0.231 & & 0.2263 & \\
\hline $\begin{array}{c}\text { Decrease percen } \\
\text { Material }(\alpha) / \text { WST }\end{array}$ & 0.97 & 0.97 & 0.94 & 0.94 & 0.91 & 0.91 & 0.88 & 0.88 & 0.85 & 0.85 & 0.82 & 0.82 & 0.79 & 0.79 & 0.76 & 0.76 & 0.73 & 0.73 \\
\hline $\begin{array}{c}\text { coefficent M } \\
\text { (p-value) }\end{array}$ & 8.4 & 0.004 & 7.163 & 0.003 & 5.037 & 0.003 & 3.983 & 0.003 & 3.357 & 0.003 & 2.944 & 0.003 & 2.653 & 0.003 & 2.438 & 0.003 & 2.385 & 0.004 \\
\hline $\begin{array}{c}\text { coefficent WST } \\
\text { (p-value) }\end{array}$ & 6.1 & 0.001 & 20.391 & 0.001 & 13.613 & 0.001 & 10.22 & 0.001 & 8.181 & 0.001 & 6.817 & 0.001 & 5.839 & 0.001 & 5.102 & 0.001 & 4.484 & 0.001 \\
\hline $\begin{array}{c}\text { Coefficent of } \\
\text { determination } \mathrm{R} 2\end{array}$ & & 0.228 & & 0.2284 & & 0.2294 & & 0.2303 & & 0.2309 & & 0.2312 & & 0.2313 & & 0.231 & & 0.2263 \\
\hline
\end{tabular}

Below are the results for the two basic models calculated Table 1a show the top patrols with always a WST value of 0.8 for good conditions respectively 1 for bad conditions. The columns show different effects of material e.g. 0.97 per execution as approximation for the reduced physical effort necessary due to improvement of material. Table $1 \mathrm{~b}$ shows the top patrols once again but the WST component was decreasing in the same way as the Material variable. Interestingly. Interestingly, in top patrols all coefficients estimated in the regression models achieve significance on an $\alpha=0.05$ level indicating a plausible association between the estimated regression models and course times allowing to suggest that an improvement of material is likely plausible to associate. Supporting this Coefficient of determination are always around 0.22 and 0.23 with a peak on the model WST $=0.82$ and MAT $=0.85$ (Figure 1). In principle the same procedures were performed for the Median patrols as for the top patrols (Table 2a \& 2b). Interestingly, the coefficient of determination was clearly deeper with values around 0.054 and 0.054. Interestingly despite clearly lower coefficient of determinations, for almost the same model as for top patrol was detected (Figure 2).
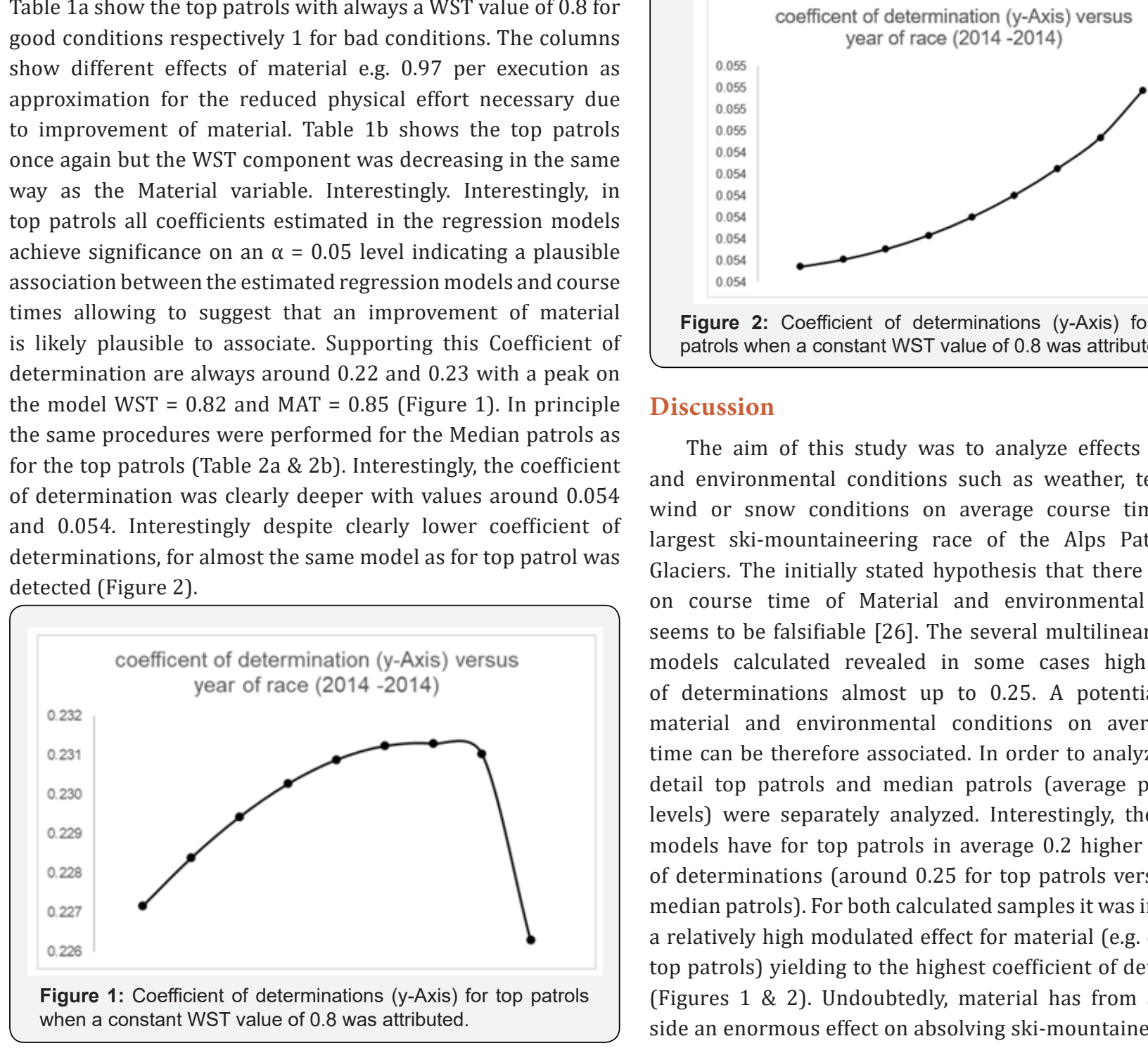

Figure 2: Coefficient of determinations (y-Axis) for median patrols when a constant WST value of 0.8 was attributed.

\section{Discussion}

The aim of this study was to analyze effects of material and environmental conditions such as weather, temperature, wind or snow conditions on average course times for the largest ski-mountaineering race of the Alps Patrouille des Glaciers. The initially stated hypothesis that there is no effect on course time of Material and environmental conditions seems to be falsifiable [26]. The several multilinear regression models calculated revealed in some cases high coefficient of determinations almost up to 0.25 . A potential effect of material and environmental conditions on average course time can be therefore associated. In order to analyze effects in detail top patrols and median patrols (average performance levels) were separately analyzed. Interestingly, the estimated models have for top patrols in average 0.2 higher coefficients of determinations (around 0.25 for top patrols versus 0.05 for median patrols). For both calculated samples it was interestingly a relatively high modulated effect for material (e.g. $\alpha=0.21$ for top patrols) yielding to the highest coefficient of determination (Figures 1 \& 2). Undoubtedly, material has from an intuitive side an enormous effect on absolving ski-mountaineering races. 
Making a simple calculation, every additional kg to carry needs additional energy released by the body. Taking the assumption of an additional one $\mathrm{kg}$ yielding to an additional potential physical performance derived from the formula Power [P] is equal to force $[\mathrm{F}]$ multiplied by distance $[\mathrm{d}](\mathrm{P}=\mathrm{F} \mathrm{x} d)=1 \mathrm{~kg}$ x $9.81 \mathrm{~m} / \mathrm{sec} 2$ x 53000 meters $=530$ '000 Joule respectively $530 \mathrm{k}$ Joule. Taking a biological efficiency factor from physical energy of one fifth around $2500 \mathrm{kj}$ additional energy consumed result. This is the energy entailed in an additional standard chocolate table pinpointing the enormous effect on weight on physical performance. Furthermore, technical reasons are to mention. With the new material a better technique on the track can be performed. It was shown for uphill ski mountaineering at a steeper gradient economy is improved, which is definitely easier to perform with the new material especially skis, shoes and bindings $[29,30]$. To sum up, the calculated models allow to suggest that there is an association between material respectively environmental factors on course times at Patrouille des Glaciers, whereby analysis in more detail are necessary to identify casual relationships of these variables.

Table 2a \& 2b: Coefficients, p-values and coefficient of determinations for the different calculated multilinear regression analysis for median patrols.

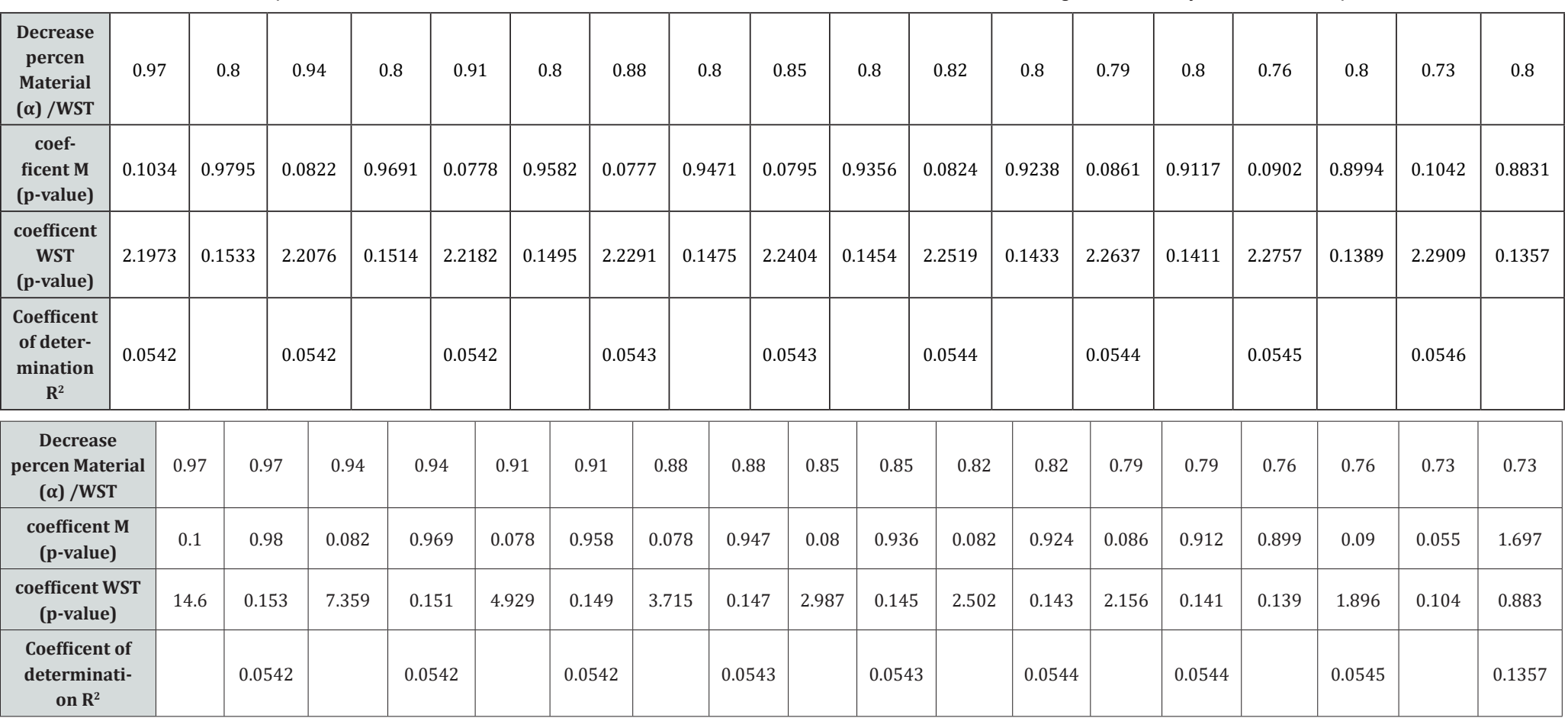

\section{References}

1. Burtscher M, Faulhaber M, Kornexl E, Nachbauer W (2005) Kardiorespiratorische und metabolische Reaktionen beim Bergwandern und alpinen Skilauf. Wiener Medizinische Wochenschrift 155: 129-135.

2. Faulhaber M, Flatz M, Burtscher M (2007) Frequency of cardiovascular diseases among ski mountaineers in the Austrian Alps. Int J Sports Med 28(1): 78-81.

3. Albisser P (1992) Kleine Wetterkunde für Bergsteiger. Bern, SAC - Verlag.

4. Winkler K, Brehm HP, Haltmeier J (2008) Bergsport Winter. Bern, SAC-Verlag, Aufl p. 2.

5. Patrouille des G (2018) Allgemeine Informationen Patrouille des Glaciers.

6. Bigard AX, Lavier P, Ullmann L, Legrand H, Douce P, et al. (1996) Branched-chain amino acid supplementation during repeated prolonged skiing exercises at altitude. Int J Sport Nutr 6(3): 295-306.

7. Diaz E, Ruiz F, Hoyos I, Zubero J, Gravina L, et al. (2010) Cell damage, antioxidant status, and cortisol levels related to nutrition in ski mountaineering during a two-day race. J Sports Sci Med 9(2): 338-346.

8. Ducret S, Zahouania H, Midola A, Lanterib P, Mathia TG (2005) Friction and abrasive wear of uhmwpe sliding on ice. Wear 258(1-4): 26-31.
9. Duc S, Cassirame J, Durand F (2011) Physiology of ski mountaineering racing. Int J Sports Med 32(11): 856-863.

10. Durand F, Kippelen P, Ceugniet F, Gomez VR, Desnot P, et al. (2005) Undiagnosed exercise-induced bronchoconstriction in ski-mountaineers. Int J Sports Med 26(3): 233-237.

11. Gutiérrez Martín M, Romero Colás S, Calvo Martínez de Laguna T, Fernández Garcés F, Vicente González J (1989) Hematologic repercussions of physical exercise in the mountains. Sangre (Barc) 34(4): 267270.

12. Praz C, Léger B, Kayser B (2014) Energy expenditure of extreme competitive mountaineering skiing. Eur J Appl Physiol 114(10): 22012211.

13. Bäurle L (2006) Sliding friction of polyethylene on snow and ice. Doctoral Thesis. ETH Zürich.

14. Bowden FP, Hughes TP (1939) The mechanism of sliding on ice and snow. Proceedings of the Royal Society of London. Series A, Mathematical and Physical Sciences 172(949): 280-298.

15. Bowden FP (1953) Friction on snow and ice. Proceedings of the Royal Society of London. Series A, Mathematical and Physical Sciences 217(1131): 462-478.

16. Colbeck SC (1988) The kinetic friction of snow. Journal of Glaciology 34(116): 78-86. 
17. Doeppenschmidt A, Butt HJ (2000) Measuring the thickness of the liquidlike layer on ice surfaces with afm. Langmuir 16: 6709-6714.

18. Doeppenschmidt A, Kappel M, Butt HJ (1998) Surface properties of ice studied by atomic force microscopy. Journal of Physical Chemistry B 102(40): 7813-7819.

19. Giesbrecht JL (2010) Polymers on snow - Towards skiing faster. Doctoral Thesis. ETH Zürich.

20. Keinonen J (1978) An experimental device for measuring friction between ski and snow. Acta Polytechnica Scandinavica. Applied Physics Series pp. 123.

21. Kuroiwa D (1977) The kinetic friction on snow and ice. Journal of Glaciology 9(81): 141-152.

22. Steffny H (2008) Dasgroße Laufbuch. München: Südwestverlag.

23. Steffny H (2010) Optimales Lauf training. München: Südwestverlag.
24. Lee KS, Koo KC, Lee SH, Cho KS, Hong CH, et al. (2018) Effect of Climatic Parameters on Acute Urinary Retention Incidence. Low Urin Tract Symptoms 10(3): 297-302.

25. Vogt M, Villiger B, Angermann M (2006) Alto - 06. Ein Höhen training shandbuch für die Praxis: Bern: Haus des Sports.

26. Popper KR (1969) Logik der Forschung. Tübingen: Mohr Siebeck.

27. Meteoschweiz (2019) Wetterdaten.

28. Munter W (2017) Drei mal drei Reduktionsmethode. Risikomanagement im Wintersport. Tappeiner Verlag. Bozen Italien.

29. Tosi P, Leonardi A, Zerbini L, Rosponi A, Schena F (2010) Energy cost and efficiency of ski mountaineering. A laboratory studies. J Sports Med Phys Fitness 50(4): 400-406.

30. Praz C, Fasel B, Vuistiner P, Aminian K, Kayser B (2016) Optimal slopes and speeds in uphill ski mountaineering: a field study. Eur J Appl Physiol 116(10): 2017-2024.

\section{Your next submission with Juniper Publishers will reach you the below assets}

- Quality Editorial service

- Swift Peer Review

- Reprints availability

- E-prints Service

- Manuscript Podcast for convenient understanding

- Global attainment for your research

- Manuscript accessibility in different formats ( Pdf, E-pub, Full Text, Audio)

- Unceasing customer service

Track the below URL for one-step submission https://juniperpublishers.com/online-submission.php 